\title{
PENINGKATAN KETERAMPILAN BERBICARA MELALUI PENDEKATAN KOMUNIKATIF KELAS V SD PADURENAN II DI BEKASI TAHUN PELAJARAN 2016/2017
}

\author{
Atie Hidayati \\ tie_28@yahoo.com \\ Pascasarjana Universitas Negeri Jakarta
}

\begin{abstract}
ABSTRAK
Tujuan dari penelitian ini adalah untuk mengetahui sejauh mana pendekatan komunikatif mampu memberikan pengaruh yang tepat pada keterampilan berbicara siswa Sekolah Dasar.Metode yang digunakan dalam penelitian ini adalah penelitian tindakan (action research). Penelitian ini dilaksanakan di SD Negeri Padurenan II, Kota Bekasidengan subyek penelitian siswa kelas V-A sejumlah 30 siswa yang terdiri atas 11 siswa laki-laki dan 19 siswa perempuan. Partisipan yang terlibat di dalam penelitian ini adalah peneliti sendiri yang berperan sebagai guru yang mengajar di kelas V-A dan guru kelas V-B sebagai kolaborator.Instrumen yang digunakan dalam penelitian iniadalah lembar observasi.Berdasarkan hasil pengolahan dan analisis data, maka kesimpulan dari hasil penelitian ini adalah Terdapat peningkatan yan signifikan keterampilan berbicara melalui pendekatan komunikatif pada siswa kelas V dengan tema satu "Benda-benda di Lingkungan Sekitar," subtema "Manusia dan Lingkungan". Pada siklus I sebanyak 19 siswa $(63,3 \%)$ tuntas, dan 11 siswa $(36,7 \%)$ belum tuntas. Sedangkan pada siklus II tema dua 'Peristiwa dalam Kehidupan", subtema "Macam-macam Peristiwa dalam Kehidupan", sebanyak 30 siswa $(100 \%)$ tuntas dengan nilai rata-rata 78,60.
\end{abstract}

Kata Kunci : berbicara, pendekatan, komunikatif

\section{PENDAHULUAN}

Bahasa mewakili yang terpenting dari semua komponen dalam kehidupan manusia. Manusia tidak akan mampu melanjutkan dan memperpanjang hidup mereka lebih baik dan teratur tanpa adanya bahasa. Mempelajari bahasa yang akan digunakan dalam kehidupan sehari-hari merupakan kebutuhan pokok manusia, karena dengan bahasa manusia akan bisa berpikir lebih baik. Bahasa dapat menghubungkan makna atau ide yang diajukan, bahasa dapat diwujudkan dalam bentuk lisan dan atau artikel. Bahasa adalah alat komunikasi untuk mengirimkan informasi, siswa belajar untuk berkomunikasi dengan yang lain melalui berbagai cara, salah satunya adalah berbicara.

Bahasa Indonesia merupakan
pelajaran yang wajib dimulai dari
pendidikan dasar hingga perguruan tinggi


dengan tujuan agar mahasiswamemiliki kemampuan bahasa dan untuk dapat mengembangkan kepribadiannya serta menerapkan bahasa Indonesia dalam komunikasi sehari-hari menjadi lebih baik dan nyata. benar. Dalam dunia pendidikan, bahasa Indonesia digunakan sebagai bahasa pengantar kegiatan sekolah di berbagai bidang sains. Hal ini menunjukkan bahasa Indonesia memegang peranan penting dalam proses pendidikan di Indonesia. Dalam Kurikulum Sekolah Dasar, studi bahasa Indonesia meliputi 4 aspek yaitu: mendengar, berbicara, membaca, dan menulis.

Pada aspek mendengarkan di sekolah dasar ada kegiatan misalnya: mendengarkan cerita guru, mendengarkan dongeng, mendengarkan drama, mendengarkan puisi anak, mendengarkan berita, mendengarkan diskusi dan juga mendengarkan wawancara. Aspek berbicara di sekolah dasar ada kegiatan misalnya: memperkenalkan diri, bercerita, orasi, discoursing, memberikan respon, diskusi, wawancara, pertemuan sederhana dan juga drama. Aspek membaca di sekolah dasar ada kegiatan misalnya: membaca pengenalan, mengenali tandatanda suara, membaca tindik, membaca dengan lancar, membaca secara teknis, membaca dalam hati, membaca dengan cepat, membaca secara kritis, membaca untuk menghormati dan juga membaca untuk mengamandemen. Aspek penulisan di sekolah dasar ada kegiatan misalnya: menulis mulai, menulis surat terpisah, menulis meluruskan bersama, menulis paragraf, menulis komposisi, menulis surat, menulis berita, menulis orasi copy dan juga menulis laporan.

Seiring pertumbuhan zaman, perubahan kurikulum telah dilakukan. Perubahan terakhir menghasilkan Kurikulum 2013 yang berorientasi pada siswa dalam mengembangkan kompetensi sikap, pengetahuan dan juga keterampilan secara terpadu melalui proses belajar siswa, dari mengajar hingga belajar. Kurikulum 2013 disusun untuk menjawab kebutuhan pendidikan abad ke-21 guna menghasilkan siswa yang produktif, kreatif, inovatif dan afektif. Dalam Kurikulum 2013 bahasa Indonesia merupakan salah satu mata pelajaran dan fungsi yang mendasar sebagai mata pelajaran rancangan pendidikan bahkan mengambil posisi sebagai bahasa draft sains.

Studi bahasa Indonesia bertujuan untuk meningkatkan keterampilan memiliki bahasa dan sastra, meningkatkan kemampuan berpikir dan memiliki eksistensi alam, dan juga kemampuan untuk 
memperluas pengetahuan. Jika tidak, siswa juga diinstruksikan untuk mempertajam perasaannya. Siswa tidak hanya diharapkan untuk dapat memahami informasi yang dikirimkan secara langsung atau tidak langsung, tetapi juga memahami informasi yang dikirimkan secara tidak langsung. Siswa tidak menjadi pintar hanya dalam memiliki eksistensi yang alami, tetapi juga memiliki efisiensi dalam interaksi sosial dan dapat menghormati perbedaan, sebaik dalam hubungan individu dan juga dalam kehidupan masyarakat, yang memiliki latar belakang berbagai agama dan budaya.

Salah satu keterampilan berbahasa berbicara. Dalam penelitian ini difokuskan pada keterampilan berbicara. Berbicara adalah kemampuan untuk mengatakan suara artikulasi atau kata-kata untuk mengekspresikan, mengekspresikan, atau mengirimkan pikiran, gagasan, dan perasaan. Untuk siswa Sekolah Dasar, keterampilan berbicara merupakan salah satu kemampuan yang harus dimiliki oleh siswa, karena keterampilan berbicara telah dimiliki oleh setiap orang yang sangat membutuhkan dalam komunikasi, baik untuk satu cara dalam karakter maupun timbal balik atau keduanya. Dengan keterampilan berbicara yang dimiliki maka siswa dapat menyampaikan pesan sehingga siswa dapat berkomunikasi dengan semua orang, juga dengan guru, dengan teman sebaya dan masyarakat pada umumnya. Selanjutnya berbicara untuk merepresentasikan keterampilan penyampaian pesan melalui bahasa lisan. Berbicara adalah salah satu keterampilan yang sangat penting yang dimiliki dan dikuasai oleh siswa. Namun kenyataan di lapangan yaitu di kelas V SDN Padurenan II masih mengalami pengalaman berbicara. Kendala di antara siswa adalah belajar untuk mengeluarkan pendapat dan aktivitas wawancara.

Deskripsi kemampuan berbicara siswa di kelas $\mathrm{V}$ saat ini adalah siswa menemukan kesulitan untuk berbicara atau gugup, kalimat cenderung pendek dan terbata-bata, siswa kurang berani atau takut dan juga tidak dapat berbicara dengan baik. Pada saat wawancara misalnya: siswa belum dapat menggunakan struktur kalimat dengan benar, mantra dan intonasi yang masih kurang tepat dan ekspresi isi yang tidak tepat isi atau pesan yang dikirimkan. Deskripsi kemampuan keterampilan berbicara siswa di kelas V terjadi karena guru mendapat fokus untuk melakukan kompetensi kegiatan belajar yang harus dicapai sehingga mengabaikan kemampuan atau dominasi berbicara dalam proses belajar siswa. Di 
samping itu, guru sering dibebani menggunakan media, sehingga sering guru memberikan instruksi kepada siswa untuk melakukan kegiatan berbicara hanya memberikan nilai dan barang jadi tanpa mengevaluasi aktivitas siswa.

Berdasarkan masalah di atas, guru perlu menerapkan pendekatan studi yang benar untuk meningkatkan keterampilan berbicara di siswa kelas $\mathrm{V}$ sekolah dasar. Salah satu pendekatan yang dapat diterapkan yaitu melalui pendekatan komunikatif. Pendekatan komunikatif mewakili studi bahasa yang memberikan kemampuan bahasa keterampilan untuk didukung oleh pengetahuan bahasa. Pendekatan komunikatif diajarkan untuk memperoleh informasi yang diperlukan dalam kehidupan sehari-hari agar siswa memahami penelitian yang lebih memiliki makna. Pendekatan komunikatif ini dapat memberikan kebebasan kepada siswa untuk mengutarakan pendapat secara lisan dan juga merangkai kata-kata untuk diberitahukan kepada teman-temannya dengan sendirinya.Pendekatan komunikatif berorientasi pada proses belajar untuk mengajarkan bahasa berdasarkan tugas dan fungsi komunikasi. Prinsip dasar pendekatan komunikatif adalah: a) item harus terdiri dari bahasa sebagai sarana komunikasi, b) item desain harus menekankan proses belajar mengajar non diskusi fundamental, c) item harus mendukung siswa untuk berkomunikasi dengan cara biasanya.

Strategi belajar mengajar dalam pendekatan komunikatif bergantung pada cara pembelajaran siswa aktif, yaitu siswa terlibat dalam proses belajar secara aktif. Strategi berdasarkan prosedur pendekatan komunikatif yaitu memendekkan presentasi dialog, mempresentasikan dialog pelatihan lisan, presentasi pertanyaan dan jawaban, observasi dan studi, penarikan kesimpulan, aktivitas interaktif, pembuatan tugas dan evaluasi pelaksanaan. Oleh karena itu, melalui pendekatan komunikasi siswa diharapkan dapat mengatur keterampilan berbicara sehingga mampu meningkatkan keterampilan berbicara yang dievaluasi sesuai, keakuratan, dan kefasihan berbicara. Melalui pembelajaran pendekatan komunikatif juga dapat mengevaluasi kekurangan siswa secara intensif dan memberikan bimbingan yang diperlukan agar aktivitas belajar lebih aktif dengan minat dan interaktif.

Dalam kaitannya dengan latar belakang masalah di atas dan didukung oleh penelitian yang relevan yang telah dilakukan oleh peneliti lain sebelumnya yaitu hasil 
penelitian "Peningkatan Keterampilan Keterampilan melalui Metode Diskusi Kelompok pada Siswa kelas V SDN Sampaka" oleh Eresia Lamajau (UNTAD, 2014) menyimpulkan melalui studi tentang metode diskusi kelompok secara efektif mengalami peningkatan aktivitas siswa dan guru dan juga hasil belajar lengkap dengan klasikal dan individu.

Penelitian tentang "Pendekatan Komunikatif Untuk Meningkatkan Keterampilan Berbicara Siswa Kelas V SD Negeri 113 Pekanbaru" oleh Rahmatul Yusna (Universitas Riau 2012) menyimpulkan pendekatan komunikatif dapat meningkatkan aktivitas belajar guru dan siswa dan juga proses belajar menjadi lebih aktif dan termotivasi. sehingga hasil belajarnya lengkap secara individu atau klasik.Dari hasil penelitian sebelumnya, satu dan kedua, dapat dilihat bahwa pendekatan komunikatif memberikan hasil yang dapat meningkatkan aktivitas belajar dan belajar siswa serta hasil belajar lengkap dengan klasikal dan individu pada kegiatan berbicara. Dengan demikian berdasarkan uraian dan juga fakta di lapangan, peneliti bermaksud untuk melakukan penelitian di kelas V tentang "Peningkatan Keterampilan Berbicara Melalui Pendekatan Komunikatif di Kelas V SD Padurenan II di Bekasi Tahun
Ajaran 2016/2017". Melalui penelitian ini diharapkan dapat diketahui sejauh mana pendekatan komunikatif mampu memberikan pengaruh yang benar pada ketrampilan peaking kepada siswa sekolah dasar secara klasik.

\section{METODE .}

Metode dalam penelitian ini adalah penelitian tindakan (action research). Penelitian bersifat partisipatif dalam arti bahwa peneliti terlibat dalam penelitian, dan bersifat kolaboratif karena terlibat dengan pihak lain (kolaborator). Penelitian menggunakan prosedur pelaksanaan pembelajaran melalui pendekatan komunikatif pada penelitian Bahasa Indonesia. Prosedur Penelitian menggunakan model prosedur penelitian dari Kemmis \& Mc Taggart yang memiliki sembilan fase, 1) mempresentasikan dialog singkat 2) mempresentasikan pelatihan lisan dialog 3) presentasi pertanyaan dan jawaban 4) analis dan studi 5) penarikan kesimpulan 6) aktivitas interpresentasi 7) aktivitas produk oral 8) hadiah tugas, dan 9) eksekusi Penelitian Subjek ini adalah siswa kelas VA Sekolah Dasar Negeri Padurenan II Kota Bekasi, Jawa Barat berjumlah 30 responden. Alat untuk mengumpulkan data yang akurat adalah dengan menggunakan lembar 
instrumen observasi. Lembar ini merupakan instrumen untuk mencatat data yang akurat sesuai dengan kejadian pada saat proses pembelajaran berlangsung. Lembar observasi berisi tentang pernyataan yang sesuai dengan indikator penelitian.

Data penelitian berupa data kuantitatif. Teknik pengumpulan data dalam penelitian ini adalah dengan teknik tes dan non tes. Pengumpulan data tes menggunakan lembar penilaian, berbicara dengan target untuk menilai pencapaian siswa setelah dilakukan oleh penelitian dalam proses belajar. Penilaian keterampilan berbicara siswa dilakukan secara manual pada instrumen grille yang telah dibuat. Hal ini dilakukan oleh peneliti sehingga dapat melihat secara kuantitatif peningkatan hasil keterampilan. Sedangkan teknik non tes dilakukan oleh 1) observasi langsung menggunakan lembar observasi tindakan pengamat belajar dan siswa selama proses pembelajaran. Observasi dilakukan sejak awal kegiatan belajar sampai akhir kegiatan studinya 2) catatan lapangan adalah untuk mencatat setiap tindakan yang dilakukan oleh guru dan siswa dan seluruh kejadian yang mempengaruhi pelaksanaan tindakan di kelas 3) dokumentasi dalam bentuk foto selama kegiatan pembelajaran berlangsung, dan 4 ) dokumentasi dalam bentuk video selama proses kegiatan keterampilan berbicara.

\section{HASIL DAN PEMBAHASAN}

Hasil temuan di lapangan mengenai pembelajaran keterampilan berbicara pada siswa kelas V D Sekolah Dasar Negeri Padurenan II Mustikajaya Bekasi melalui pendekatan komunikatif. Peneliti berperan sebagai perencana, pelaksana, dan pengajar di kelas selama penelitian tindakan kelas berlangsung.Penelitian dilaksanakan selama dua siklus, tiap siklus terdiri dari dua kali pertemuan.Alokasi waktu tiap pertemuan adalah 70 menit ( 2 x 35 menit).Pelaksanaan masing-masing siklus melalui beberapa tahapan, yaitu perencanaan (planning), pelaksanaan tindakan (acting), pengamatan (observing), dan refleksi (reflecting).

\section{Prasiklus}

Pelaksanaan prasiklus pada rangkaian penelitian ini untuk mengetahui kondisi pembelajaran keterampilan berbicara sebelum diberi tindakan.Peneliti melaksanakan prasiklus pada tanggal 12September 2017 dengan alokasi waktu 2 x 35 menit. Pembelajaran berlangsung pada tema1, "Benda-benda di Lingkungan Sekitar" subtema 1 "Wujud benda dan Cirinya, pembelajaran 4 dengan indikator 
mengeluarkan pendapat tentang keseimbangan alam.

Adapun hasil keterampilan berbicara dapat dilihat pada tabel dibawah ini:

\begin{tabular}{|c|c|c|c|}
\hline \multirow{2}{*}{$\begin{array}{c}\text { Interval } \\
\text { Nilai }\end{array}$} & Frekuensi & $\begin{array}{c}|c| \\
\text { Relatif } \\
(\%)\end{array}$ & Kumulatif \\
\cline { 2 - 4 } & 4 & 13.33 & 13.33 \\
\hline $14-27$ & 8 & 26.67 & 40.00 \\
\hline $28-40$ & 5 & 16.67 & 56.67 \\
\hline $41-53$ & 4 & 13.33 & 70.00 \\
\hline $54-66$ & 3 & 10 & 80.00 \\
\hline $67-79$ & 3 & 10 & 90.00 \\
\hline $80-92$ & 3 & 10 & 100.00 \\
\hline $93-100$ & $\mathbf{3 0}$ & $\mathbf{1 0 0}$ & \\
\hline Jumlah & & & \\
\hline
\end{tabular}

\section{Tabel 1. Distribusi Hasil Keterampilan} Berbicara Prasiklus

Berdasarkan data pada tabel 1 maka nilai keterampilan berbicara siswa pada prasiklus, menunjukan perolehan yang paling banyak nilai 28-40 berjumlah 8 siswa, kemudian nilai 41-53 berjumlah 5 siswa, untuk nilai 14-27 dan 54-65 berjumlah 4 siswa. Hasil tersebut menunjukkan bahwa hasil keterampilan berbicara siswa masih rendah sehingga perlu tindakan untuk pembelajaran selanjutnya. Adapun tabel hasil ketuntasanketerampilan berbicara siswa prasiklus sebagai berikut.
Tabel 2. Hasil ketuntasan Keterampilan Berbicara Prasiklus

\begin{tabular}{|c|c|c|}
\hline $\begin{array}{c}\text { Hasil } \\
\text { Keterampilan } \\
\text { Berbicara }\end{array}$ & $\begin{array}{c}\text { Jumlah } \\
\text { Siswa }\end{array}$ & Persentase \\
\hline Tuntas & 10 & $33,33 \%$ \\
\hline Belum Tuntas & 20 & $66,67 \%$ \\
\hline Jumlah & 30 & $100 \%$ \\
\hline
\end{tabular}

Dari data tabel di atas, dapat diketahui bahwa hasil tes prasiklus menunjukkan bahwa nilai rata-rata siswa mencapai 37,8 . Dengan KKM 70, maka dari 30 siswa yang tuntas berjumlah 10 siswa dan yang belum tuntas berjumlah 20 siswa. Adapun gambaran secara visual hasil prasiklus pada diagram di bawah ini:

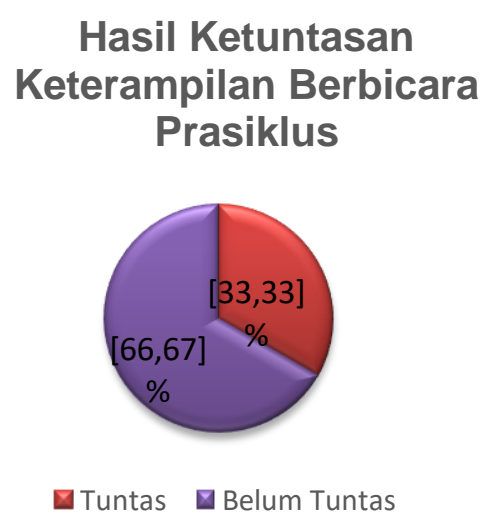

Gambar 1: Diagram Lingkaran Hasil Ketuntasan Keterampilan Berbicara Prasiklus 
Berdasarkan paparan di atas dapat disimpulkan bahwa kondisi pembelajaran keterampilan berbicara masih rendah sebagai berikut: 1). Pada proses pembelajaran guru tidak memperhatikan kegiatan keterampilan berbicara, ketika siswa tampil danya menangkap awal berbicara saja; 2). Guru hanya menggunakan media gambar yang terdapat pada buku siswa; 3). Antusias siswa dalam pembelajaran berbicara masih kurang karena masih menggunakan tehnik ceramah; 4). Tidak terdapatnya contoh yang dapat dilihat siswa misalnya melalui video sehingga dapat terlihat siswa mengalami kesulitan berbicara atau gugup, kalimat tidak jelas seolah bergumam, siswa kurang berani atau takut serta tidak dapat berbicara dengan baik. Oleh karena itu, perlu adanya tindakan terhadap pembelajaran yang dapat berdampak positif terhadap peningkatan keterampilan berbicara.

\section{Siklus I}

Berdasarkan hasil evaluasi pada tema satu "Benda-Benda di Lingkungan Sekitar" mengenai " Manusia dan Lingkungannya", hasil keterampilan berbicara diperoleh dari tes yang diberikan pada di akhir siklus I berupa tes menyajikan dan mempresentasikan hasil wawancara dalam bentuk laporan. Hal ini dilakukan untuk melihat sejauh mana terjadinya peningkatan keterampilan berbicara dan menuangkannya dalam bentuk tulisan melalui pendekatan komunikatif. Berikut ini disajikan hasil pengolahan data hasil belajar siswa dalam tabel di bawah ini

\section{Tabel 3.Distribusi Hasil Keterampilan Berbicara}

\begin{tabular}{|c|c|c|c|}
\hline \multirow{2}{*}{$\begin{array}{c}\text { Interval } \\
\text { Nilai }\end{array}$} & Frekuensi & $\begin{array}{c}|c| \\
\text { Jumlah Siswa } \\
(\%)\end{array}$ & Kumulatif \\
\cline { 2 - 4 } & 11 & 36.67 & 36.67 \\
\hline $61-60$ & 2 & 6.67 & 43.33 \\
\hline $68-74$ & 4 & 13.33 & 56.67 \\
\hline $75-81$ & 6 & 20.00 & 76.67 \\
\hline $82-88$ & 1 & 3 & 80.00 \\
\hline $89-95$ & 5 & 17 & 96.67 \\
\hline $96-100$ & 1 & 3 & 100.00 \\
\hline Jumlah & $\mathbf{3 0}$ & $\mathbf{1 0 0}$ & \\
\hline
\end{tabular}

Berdasarkan data pada table di atas, hasil keterampilan berbicara menunjukkan perolehan paling banyak pada nilai 54-60 yaitu sebanyak 11 siswa dengan persentase $36,67 \%$. Selanjutnya dideskripsikan bahwa siswa yang tuntas berjumlah 19 siswa $(63,3$ $\%$ ) dan yang belum tuntas berjumlah 11 siswa $(36,7 \%)$. Evaluasi keterampilan berbicara pada ranah kognitif dan 
psikomotor diperoleh rata-rata 71,16 . Hal tersebut menunjukkan bahwa keterampilan berbicara belum mencapai target yang telah ditentukan. Adapun tabel ketuntasan hasil keterampilan berbicara siswa pada tahap siklus I adalah sebagai berikut:

Tabel 4. Hasil Ketuntasan Keterampilan Berbicara Siklus I

\begin{tabular}{|c|c|c|}
\hline $\begin{array}{c}\text { Hasil Keterampilan } \\
\text { Menulis Laporan }\end{array}$ & $\begin{array}{c}\text { Jumlah } \\
\text { Siswa }\end{array}$ & $\begin{array}{c}\text { Perse } \\
\text { ntase }\end{array}$ \\
\hline Tuntas & 19 & $\begin{array}{c}63,3 \\
\%\end{array}$ \\
\hline Belum Tuntas & 11 & $\begin{array}{c}36,7 \\
\%\end{array}$ \\
\hline Jumlah & 30 & $100 \%$ \\
\hline
\end{tabular}

Berdasarkan dari tabel di atas, hasil keterampilan berbicara siswa belum memenuhi target yang diharapkan. Oleh karena itu perlu adanya tindakan selanjutnya pada siklus II. Peneliti harus memperbaiki kekurangan yang ditemukan selama pembelajaran di siklus I sehingga hasil keterampilan menulis laporan dapat lebih meningkat. Untuk mendapatkan gambaran secara visual mengenai hasil keterampilan berbicara siswa pada setiap indikator, dapat disajikan dalam diagram berikut:

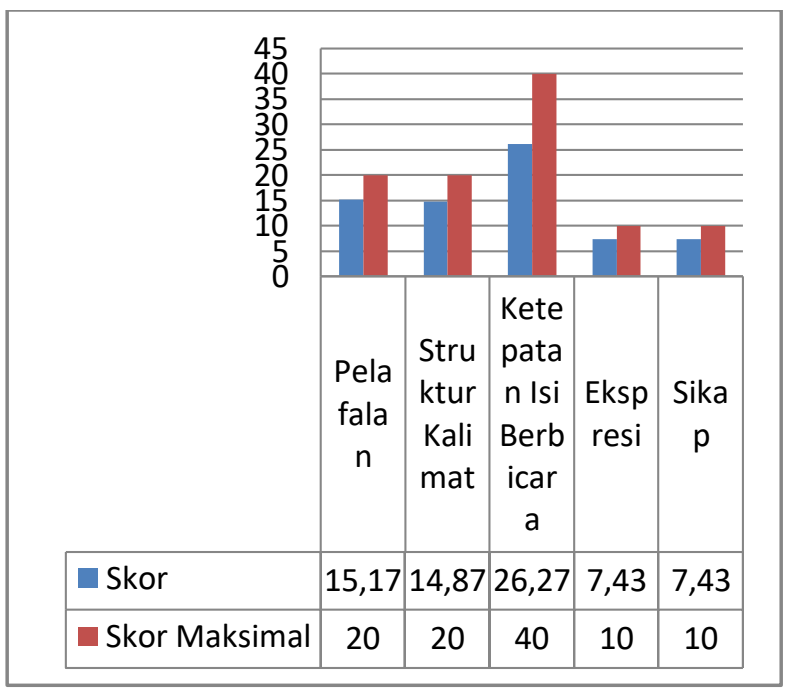

Gambar 2: Diagram Batang Pencapaian
Indikator Keterampilan Berbicara Siklus
I

Adapun hasil penilaian setiap indikator menunjukkan bahwa indikator pelafalan mencapai skor rata-rata 15,17 dari skor maksimal 20, indikator struktur kalimat mencapai skor 14,87 dari skor minimal 20, ketepatan isi berbicara mencapai skor ratarata 26,27 dari skor maksimal 40 , indikator ekspresi mencapai skor rata-rata 7,43 dari skor maksimal 10, dan indikator sikap mencapai skor rata-rata 7,43 dari skor maksimal 10. Data tersebut menunjukkan telah terjadi peningkatan jika dibandingkan dengan perolehan skor rata-rata tiap indikator pada pra siklus. 
Peningkatan keterampilan berbicara terjadi karena siswa melaksanakan kegiatan belajar dengan pendekatan komunikatif. Guru bersama siswa melaksanakan pembelajaran keterampilan berbicara dengan melibatkan kemampuan agar tujuan pembelajaran pada kriteria yang dinilai tercapai, yaitu: pelafalan/pengucapan/intonasi, struktur kalimat, ketepatan isi berbicara, ekspresi dan sikap.

\section{Siklus II}

Berdasarkan hasil evaluasi pada tema dua "Peristiwa Dalam kehidupan" dmengenai "Macam-macam peristiwa Dalam Kehidupan". hasil keterampilan berbicara diperoleh dari tes yang diberikan pada di akhir siklus II berupa tes menyajikan dan mempresentasikan hasil wawancara dalam bentuk laporan. Hal ini dilakukan untuk melihat sejauh mana terjadinya peningkatan keterampilan berbicara dan menuangkannya dalam bentuk tulisan melalui pendekatan komunikatif. Berikut ini disajikan hasil pengolahan data hasil belajar siswa dalam tabel di bawah ini:

\section{Tabel 5. Distribusi Hasil keterampilan Berbicara Siklus II}

\begin{tabular}{|c|c|c|c|}
\hline \multirow{2}{*}{$\begin{array}{c}\text { Interval } \\
\text { Nilai }\end{array}$} & \multicolumn{3}{|c|}{ Jumlah Siswa } \\
\cline { 2 - 4 } & Frekuensi & $\begin{array}{c}\text { Relatif } \\
(\%)\end{array}$ & Kumulatif \\
\hline $70-74$ & 11 & 36.67 & 36.67 \\
\hline $75-79$ & 10 & 33.33 & 70.00 \\
\hline $80-84$ & 2 & 6.67 & 76.67 \\
\hline $85-89$ & 0 & 0 & 76.67 \\
\hline $90-94$ & 6 & 20.00 & 96.67 \\
\hline $95-99$ & 1 & 3.33 & 100.00 \\
\hline Jumlah & $\mathbf{3 0}$ & $\mathbf{1 0 0}$ & \\
\hline
\end{tabular}

Berdasarkan data pada tabel di atas, hasil keterampilan berbicara menunjukkan perolehan paling banyak pada nilai 70-74 yaitu sebanyak 11 siswa dengan persentase $36.67 \%$. Berdasarkan atas Kriteria Ketuntasan Minimal (KKM) yang telah ditetapkan yaitu 70, diketahui bahwa yang tuntas seluruh siswa dengan jumlah 30 siswa (100 \%). Evaluasi keterampilan berbicara diperoleh dengan skor rata-rata 79.00. Hal tersebut menunjukkan bahwa keterampilan berbicara siswa telah mencapai target yang diharapkan. Untuk mendapatkan gambaran secara visual mengenai hasil keterampilan berbicara siswa pada setiap indikator, dapat disajikan dalam diagram berikut 


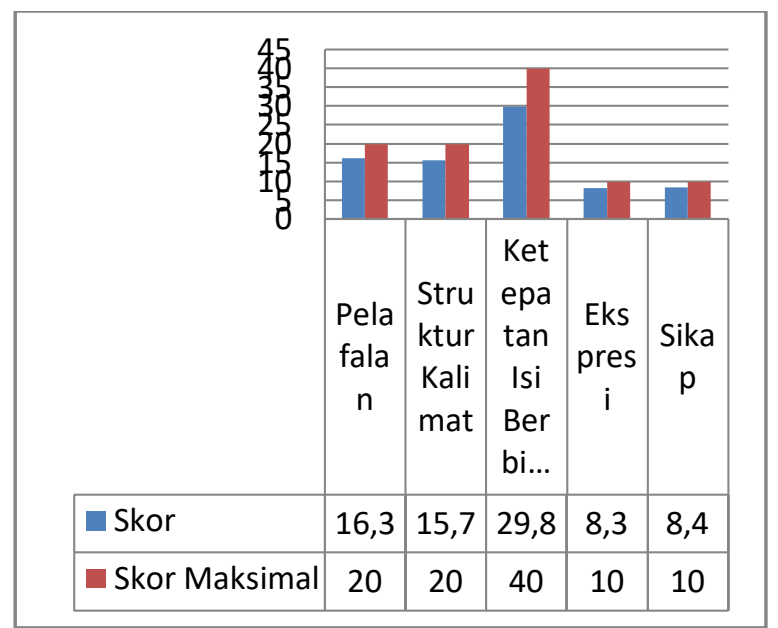

Gambar 3: Diagram Batang Pencapaian Indikator Keterampilan Berbicara Siklus II

Hasil keterampilan berbicara pada siklus II sama halnya dengan siklus I, terdapat lima indikator yang dijadikan rubrik penilaian keterampilan berbicara siswa, yaitu pelafalan/pengucapan/intonasi, struktur kalimat, ketepatan isi berbicara, ekspresi dan sikap. Dari hasil penilaian keterampilan berbicara menunjukkaan bahwa tujuh siswa $(23,33 \%)$ yang mendapat skor antara 85 100 (Kriteria A), 12 siswa $(40,00 \%)$ yang mendapat skor antara $75-84$ (Kriteria B), 11 siswa $(36,67 \%)$ mendapat skor antara 60 - 74 (Kriteria C). Maka rata - rata nilai siswa sebesar 79.00 .

Adapun hasil penilaian setiap indikator menunjukkan bahwa indikator pelafalan mencapai skor rata-rata 16,3 dari skor maksimal 20, indikator struktur kalimat mencapai skor 15,7 dari skor maksimal 20, ketepatan isi berbicara mencapai skor ratarata 29,8 dari skor maksimal 40, indikator ekspresi mencapai skor rata-rata 8,3 dari skor maksimal 10, dan indikator sikap mencapai skor rata-rata 8,4 dari skor maksimal 10. Data tersebut menunjukkan telah terjadi peningkatan jika dibandingkan dengan perolehan skor rata-rata tiap indikator pada pra siklus.

Pada siklus II siswa yang tuntas berjumlah 30 siswa. Adapun tabel ketuntasan hasil keterampilan menulis laporan siswa pada tahap siklus II adalah sebagai berikut:

Tabel 6. Hasil Ketuntasan Keterampilan Menulis Laporan Siklus II

\begin{tabular}{|c|c|c|}
\hline $\begin{array}{c}\text { Hasil Keterampilan } \\
\text { Menulis Laporan }\end{array}$ & $\begin{array}{c}\text { Jumlah } \\
\text { Siswa }\end{array}$ & $\begin{array}{c}\text { Perse } \\
\text { ntase }\end{array}$ \\
\hline Tuntas & 30 & $100 \%$ \\
\hline Belum Tuntas & - & - \\
\hline Jumlah & 30 & $100 \%$ \\
\hline
\end{tabular}

Berdasarkan tabel di atas hasil keterampilan berbicara siswa telah memenuhi target yang diharapkan, maka penelitian peningkatan keterampilan berbicara melalui pendekatan komunikatif pada siswa kelas V SDN Padurenan II dihentikan pada siklus II. 


\section{SIMPULAN}

Simpulan hasil penelitian, yaitu adanya peningkatan keterampilan berbicara melalui pendekatan komunikatif pada siswa kelas V dengan tema satu "Benda-benda di Lingkungan Sekitar," subtema "Manusia dan Lingkungan".Hasil keterampilan berbicara siswa mengalami peningkatan yang signifikan. Hal tersebut terbukti dengan siswa yang dinyatakan tuntas pada siklus I, diketahui sebanyak 19 siswa (63,3\%) dan yang belum tuntas sebanyak 11 siswa $(36,7$ $\%)$. Evaluasi keterampilan mendengarkan pada siklus I diperoleh rata-rata 71,17. Peningkatan keterampilan berbicara mendekati target dan nilai siswa hanya ada beberapa yang masih di bawah rata-rata kriteria ketuntasan minimal.

Hasil keterampilan berbicara melalui pendekatan komunikatif pada siklus II tema dua 'Peristiwa dalam Kehidupan", subtema "Macam-macam Peristiwa dalam Kehidupan". Diketahui bahwa yang tuntas sebanyak 30 siswa $(100 \%)$. Hal ini menunjukkan adanya peningkatan keterampilan berbicara pada siklus II dengan memperoleh rata-rata 78,60. Pada pelaksanaan tindakan siklus II, peneliti telah memenuhi target yang telah ditentukan dan diharapkan, maka penelitian peningkatan keterampilan berbicara melalui pendekatan komunikatif pada siswa kelas V Sekolah Dasar Negeri Padurenan II dihentikan pada siklus II. Hal tersebut membuktikan bahwa, pendekatan komunikatif dapat meningkatkan keterampilan berbicara siswa kelas V Sekolah Dasar Negeri Padurenan II, Kecamatan Mustikajaya, Kota Bekasi.

\section{DAFTAR PUSTAKA}

Arsjad, Maidar G. \& Mukti U.S. 1998. Pembinaan Kemampuan Berbicara bahasa Indonesia. Jakarta: Erlangga.

Asih. 2015. Strategi Pembelajaran Bahasa Indonesia, Bandung:Pustaka Setia.

Azie Furqanul \& Chaedar Alwasilah. 2002. Pengajaran Bahasa Komunikatif. Bandung: Rosda.

Eggen, Paul \& Don Kauchak. 2007. EdicationalPsychology. Usa:Pearson.

Ghazali, Syukur. Pembelajaran Keterampilan Berbahasa. Bandung;Aditama.

Hopkins, David. 2011. Panduan Guru Penelitian Tindakan Kelas (A Teacher's Guide Classroom Research).Yogyakarta: Pustaka Belajar.

Hurlock, Elizabeth B. 2002. PsikologiPerkembangan. Jakarta: Erlangga.

Madya, Suwarsih. 2011. Penelitian Tindakan Action Research . Bandung: Alfabeta

Meleong, Lexy. 2005. Metodologi Penelitian Kualitatif. Bandung: Remaja Rosda karya.

Nurgiyantoro, Burhan. 2014. Penilaian Pembelajaran Bahasa. Yogyakarta: BpFE. 
Nurjamal, Daeng. 2014. Terampil Berbahasa. Bandung: Alfabeta.

Sukardi. 2005. Metodologi Penelitian Pendidikan Kompetensi dan Praktiknya. Jakarta: Bumi Aksara.

Sumadayo, Samsu. 2013. Penelitian Tindakan Kelas. Yogyakarta: Graha Ilmu

Suyadi. 2012.Buku Panduan Guru Profesional Penelitian Tindakan Kelas (PTK) dan Penelitian Tindakan Sekolah (PTS). Yogyakarta: Penerbit ANDI

Tarigan, Djago. 1996. Teknik Pengajaran Keterampilan Berbahasa. Bandung: Angkasa.

Tanujaya, Benediktus \& Jeinne Mumu. 2015. Penelitian Tindakan kelas, Yogyakarta: Media Akademi

Tarigan, Henry Guntur. 2015. Berbicara Sebagai Suatu Keterampilan Berbahasa. Bandung: Angkasa.

Trianto, 2011. Panduan Penelitian Tindakan Kelas (Classroom Action Research) Teori \& Praktek. Jakarta: Prestasi Pustaka Raya

Wassid, Iskandar \& Dadang Suhendar. 2016. Strategi Pembelajaran Bahasa. Bandung;Rosda.

Wiriatmadja, Rochiati. Metode Penelitian Tindakan Kelas. Bandung;Remaja Rosdakarya.

Zulela, 2013. Pembelajaran Bahasa Indonesia. Bandung: Rosda. 